\title{
Global distribution of entomopathogenic nematodes, Steinernema and Heterorhabditis
}

\author{
Aashaq Hussain Bhat ${ }^{1}$, Ashok Kumar Chaubey ${ }^{1}$ and Tarique Hassan Askary ${ }^{2 *}$
}

\begin{abstract}
Entomopathogenic nematodes (EPNs) in the families' Steinernematidae and Heterorhabditidae are obligate insect parasites. Their easy multiplication, broad host range, compatibility with chemical pesticides, and ease in application has grabbed interest among research practitioners to work on these beneficial microorganisms. Till date, around 100 valid species of Steinernema and 21 species of Heterorhabditis have been identified from different countries of the world. Extensive surveys have been conducted across the globe to isolate locally adapted EPN species and exploit them to suppress soil-dwelling and foliar insect pests in agricultural fields. Most of the new species have been described from Asia, whereas research in some Asian countries are still at infancy. Some new species have been recorded from Australia but very few surveys have been conducted in New Zealand. Likewise, less information about these tiny creatures is from Central America; however, in North America many new species have been described, some of which have been commercialized for insect pest control, whereas in South America, several native nematode species have been described and exploited as biological control agents. European countries have also been explored for EPN diversity and new species have been reported, exploited under field condition, and commercialized. Many new species and other previously described species have been reported from Africa. Despite frequent surveys in different continents of the world, number of sites touched are low and, therefore, further surveys are still needed to explore untouched geographic areas and climatic conditions, both in plantations and indigenous forests with an aim to identify and exploit additional EPN species.
\end{abstract}

Keywords: Entomopathogenic nematodes, Distribution, Biocontrol, Insect pests

\section{Background}

Steinernematidae Travassos, 1927 and Heterorhabditidae Poinar Jr, 1975 are the two important nematode families, which have drawn attention throughout the world as they have proven promising biocontrol agents of agriculturally important insect pests of soil, foliar, and cryptic habitats (Askary, 2010; Askary and Abd-Elgawad, 2017). The work on entomopathogenic nematodes (EPNs) is believed to have been initiated from Germany where the first species of EPN was described (Steiner, 1923a, b). Later, it spread to New Jersey, USA where a new species was reported that was attacking white grubs and this

\footnotetext{
* Correspondence: tariq_askary@rediffmail.com

${ }^{2}$ Division of Entomology, Faculty of Agriculture, Sher-e-Kashmir University of Agricultural Sciences \& Technology of Kashmir, Wadura Campus, Sopore, Jammu \& Kashmir 193201, India

Full list of author information is available at the end of the article
}

biocontrol attribute became a turning point for exploration of EPN species from other parts of the world. Extensive studies on EPNs were carried out in the 19th and 20th centuries, which led to a tremendous research on taxonomy and commercialization of steinernematids and heterorhabditids and currently the interest of using them as alternatives to chemical pesticides is paying much attention throughout the world. The use of EPNs in biological control of insect pests brought attention of research practitioners throughout the globe and more researchers became interested in working on EPNs and exploiting them at commercial level.

Surveys have been conducted from almost all parts of the world in order to isolate locally adapted EPN species or isolates with further aim to formulate and commercialize them (Hominick et al, 1996; Hominick, 2002). This led to the increase in described species of 
EPNs from 13 (10 Steinernema and 3 Heterorhabditis) in the late 1980s (Kaya and Gaugler, 1993) to 66 (55 Steinernema and 11 Heterorhabditis) in 2007 (Hunt, 2007; Nguyen et al., 2007). Based on molecular data, Hunt and Subbotin (2016) and Hunt and Nguyen (2016) updated the species list of Steinernema and Heterorhabditis and found several species invalid. Though, surveys to identify local species of EPNs has increased in the past 3 decades, knowledge on the diversity of these beneficial nematodes is still limited, particularly in many forest areas and hilly regions of the developed and developing countries of the world.

In the foregone review, our aim is to highlight the work done on isolation and identification of EPNs in different continents of the world (Tables 1 and 2). Emphasis has been laid for further investigations in this direction in order to identify additional native species and their exploitation for insect pest management programs.

\section{North America}

Steinernematids reported from North America include S. glaseri (Glazer and Fox, 1930) from Popillia japonica (New Jersy); S. intermedium (Poinar Jr, 1986) from soil (Charleston, South Carolina, USA); S. neocurtillae (Nguyen and Smart Jr, 1992) from Neocurtilla hexadactyla (Florida USA); S. cubanum (Mráček et al, 1994) from soil samples (Cuba); S. riobrave (Cabanillas et al., 1994) from soil (Weslaco,Texas USA); S. puertoricense (Román and Figueroa, 1994) from soil (Loiza, Puerto Rico); S. oregonense (Liu and Berry, 1996) from soil (Oregon USA); S. diaprepesi (Nguyen and Duncan, 2002) from Diaprepes abbreviates (Florida); S. scarabaei (Stock and Koppenhöfer, 2003) from Anomala (= Exomala) orientalis and Popillia japonica (New Jersey, USA); S. jollieti (Spiridonov et al., 2004) from soil (Missouri valley near St. Louis, USA); S. costaricense (Uribe-Lorío et al., 2007) from soil (Costa Rica); $S$. puntauvense (Uribe-Lorío et al., 2007) from soil (Costa Rica); S. texanum (Nguyen et al., 2007) from soil (Texas, USA); S. phyllophagae (Nguyen and Buss, 2011) from White grub (Phyllophaga sp.) (Florida, USA). Among heterorhabditids, new descriptions include $H$. megidis (Poinar Jr et al., 1987) from Popillia japonica (Ohio, USA); H. hepialius (Stock et al., 1996), currently synonymized with $H$. marelatus, from Hepialus californicus (California); H. marelatus (Liu \& Berry, 1996) from soil (Oregon); H. mexicana (Nguyen et al., 2004a) from soil (Mexico); H. floridensis (Nguyen et al, 2006a) from soil (Florida, USA), and $H$. georgiana (Nguyen et al., 2008b) from soil sample (Georgia, USA). In Florida, one more genus of family Steinernematidae, Neosteinernema longicurvicauda (Nguyen and Smart Jr, 1994), has been isolated from termite (Reticulitermes flavipes), which had not been recorded from anywhere, since its discovery.
The beginning of in vitro mass production and field testing of steinernematid nematodes began in North America in the late 1930s by Glaser and his co-workers (Gaugler et al., 1992) and Dutky in the 1950s (Dutky, 1959). In vitro production at commercial level was made possible by producing nematodes monoxenically using a solid-state culture technique (Friedman, 1990; Gaugler and Han, 2002). Bedding developed sponge-based technology, which on one-hand made harvesting of nematodes easy (Friedman, 1990); however, it was labor intensive. Later, liquid fermentation methods of nematode production were introduced (Ehlers, 2001; Friedman, 1990; Gaugler and Han, 2002; Georgis, 2002) but for cottage industries, it was not economically feasible due to requirement of high initial capital investment to purchase and operate bioreactors. Thus, production of nematodes in cottage industries relied on in vivo or in vitro solid-state production scheme developed by Bedding (Gaugler and Han, 2002). In North America, two European companies' viz., e-nema and Koppert distribute their nematode products. The commercially used EPNs in North America are S. carpocapsae (Weiser), S. feltiae (Filipjev), S. glaseri (Steiner), S. kraussei (Steiner), S. riobrave (Cabinillas, Poinar and Raulston), S. scapterisci (Nguyen and Smart), H. bacteriophora (Poinar), H. indica (Poinar, Karunakar and David), H. megidis (Poinar, Jackson and Klein), H. marelatus (Liu and Berry), and a Heterorhabditis species (Georgis et al., 2006).

\section{Central America}

The EPN isolates recorded from Central America included S. carpocapsae from Chihuahua (Poinar, 1990) and $H$. indica from a subtropical region in Mexico (La Sierra, Tabasco) (Cortez-Madrigal et al., 2003). Many other isolates of Steinernema and Heterorhabditis were also reported (Diaz-Mederos et al., 2002, Alia et al, 2002, Ruiz-Vega et al., 2003, Cortez-Madrigal et al, 2003; Molina-Ochoa et al., 2003a, b, c; Uribe-Lorio et al., 2005), but their species status needs confirmation. A new species H. mexicana Nguyen, Shapiro-Ilan, Stuart, McCoy, James, and Adams has been reported from Tamaulipas (Nguyen et al. 2004a). The biological control traits of this species have been worked out by Shapiro-Ilan et al. (2005).

\section{South America}

The work on EPNs has been reported from seven South American countries that included Argentina, Brazil, Chile, Colombia, Peru, Suriname, and Venezuela. The first report of Heterorhabdits previously referred as Rhabditis hambletoni was reported by Pereira (1937). Pizano et al. (1985) reported S. glaseri (originally described from Popillia japonica from North America) from the egg of Migdolus fryanus (Westwood) obtained 
Table 1 List of Steinernema species recorded from different countries of the world

\begin{tabular}{|c|c|c|c|c|}
\hline S. no. & Species & Authors \& year & Host insect/soil & Location \\
\hline 1 & S. abbasi & Elawad et al., 1997 & Soil & Sultanate of Oman \\
\hline 2 & S. aciari & Qiu et al., 2005a & Soil & China \\
\hline 3 & S. affine & (Bovien, 1937) Wouts et al., 1982 & Phyla febrilis (L.) & Denmark \\
\hline 4 & S. akhursti & Qiu et al., 2005b & Soil & China \\
\hline 5 & S. anatoliense & Hazir et al., 2003 & Soil & Turkey \\
\hline 6 & S. apuliae & Triggiani et al., 2004 & Soil & Italy \\
\hline 7 & S. arasbaranense & Nikdel et al., 2011 & Soil & Iran \\
\hline 8 & S. arenarium & (Artyukhovsky et al., 1997) Wouts et al. 1982 & Soil & Central Russia \\
\hline 9 & S. ashivense & Phan et al., 2006b & Soil & Japan \\
\hline 10 & S. asiaticum & Anis et al., 2002 & Soil & Pakistan \\
\hline 11 & S. australe & Edgington et al., 2009b & Soil & Chile \\
\hline 12 & S. backanense & Phan et al., 2006a & Soil & Vietnam \\
\hline 13 & S. beddingi & Qiu et al., 2005c & Soil & China \\
\hline 14 & S. beitlechemi & Çimen et al., 2016 & Soil & South Africa \\
\hline 15 & S. bicornutum & Tallosi et al., 1995 & Soil & Strazilovo, Serbia \\
\hline 16 & S. biddulphi & Çimen et al., 2016 & Soil & South Africa \\
\hline 17 & S. boemarei & Lee et al., 2009 & Soil & France \\
\hline 18 & S. borjomiense & Gorgadze et al., 2018 & Oryctes nasicornis & Georgia \\
\hline 19 & S. brazilense & Nguyen et al., 2010 & Soil & Mato Grosso, Brazil \\
\hline 20 & S. cameroonense & Kanga et al., 2012 & Soil & Cameroon \\
\hline 21 & S. carpocapsae & (Weiser 1955) Wouts et al. 1982 & Cydia pomonella (L.) & Czechoslovakia \\
\hline 22 & S. caudatum & Xu et al., 1991 & Soil & China \\
\hline 23 & S. ceratophorum & Jian et al., 1997 & Soil & Jining Province, China \\
\hline 24 & S. changbaiense & Ma et al., 2012a, b, c & Soil & China \\
\hline 25 & S. cholashanense & Nguyen et al., 2008a & Soil & China \\
\hline 26 & S. citrae & Malan et al., 2011 & Soil & South Africa \\
\hline 27 & S. colombiense & Lopez-Nunez et al., 2008 & Soil & Colombia \\
\hline 28 & S. costaricense & Uribe-Lorío et al., 2007 & Soil & Costa Rica \\
\hline 29 & S. cubanum & Mráček et al., 1994 & Soil & Western Cuba \\
\hline 30 & S. cumgarense & Phan et al., 2006a & Soil & Vietnam \\
\hline 31 & S. diaprepesi & Nguyen and Duncan, 2002 & Diaprepes abbreviates & Florida \\
\hline 32 & S. eapokense & Phan et al., 2006a & Soil & Vietnam \\
\hline 33 & S. ethiopiense & Tamirou et al., 2012 & Soil & Ethiopia \\
\hline 34 & S. fabii & Abate et al., 2016 & Soil & South Africa \\
\hline 35 & S. feltiae & (Filipjev, 1934) Wouts et al. 1982 & Agrotis segetum & Denmark \\
\hline 36 & S. glaseri & (Steiner, 1929) Wouts et al., 1982 & Popillia japonica & New Jersey, USA \\
\hline 37 & S. goweni & San-Blas et al., 2016 & Soil & Venezuela \\
\hline 38 & S. guangdongense & Qui et al., 2004 & Soil & China \\
\hline 39 & S. hebeiense & Chen et al., 2006 & Soil & China \\
\hline 40 & S. hermaphroditum & Stock et al., 2004 & Soil & Indonesia \\
\hline 41 & S. huense & Phan et al., 2014 & Soil & Vietnam \\
\hline 42 & S. ichnusae & Tarasco et al., 2008 & Soil & Sardinia Island, Italy \\
\hline 43 & S. innovationi & Çimen et al., 2015 & Soil & South Africa \\
\hline 44 & S. intermedium & (Poinar, 1985) Mamiya 1988 & Soil & Charleston, South Carolina, USA \\
\hline
\end{tabular}


Table 1 List of Steinernema species recorded from different countries of the world (Continued)

\begin{tabular}{|c|c|c|c|c|}
\hline S. no. & Species & Authors \& year & Host insect/soil & Location \\
\hline 45 & S. jeffreyense & Malan et al., 2015 & Soil & South Africa \\
\hline 46 & S. jollieti & Spiridonov et al., 2004 & Soil & Missouri valley near St. Louis, USA \\
\hline 47 & S. karii & Waturu et al., 1997 & Soil & Kirinyaga, Central Province, Kenya \\
\hline 48 & S. khoisanae & Nguyen et al., 2006a, b & Soil & South Africa \\
\hline 49 & S. khuongi & Stock et al., 2019 & Soil & Florida \\
\hline 50 & S. kraussei & $\begin{array}{l}\text { (Steiner, 1923a, b) Travassos } 1927 \\
=\text { Type species }\end{array}$ & Cephaleia abietis (L.) & Germany \\
\hline 51 & S. kushidai & Mamiya, 1988 & Anomala cuprea Hope & Hamikita, Japan \\
\hline 52 & S. lamjungense & Khatri-Chhetri et al., $2011 \mathrm{a}$ & Soil & Nepal \\
\hline 53 & S. leizhouense & Nguyen et al., 2006b & Soil & Southern China \\
\hline 54 & S. litchii & Steyn et al., 2017 & Soil & South Africa \\
\hline 55 & S. litorale & Yoshida, 2004 & Soil & Japan \\
\hline 56 & S. loci & Phan et al., 2001c & Soil & Vietnam \\
\hline 57 & S. longicaudum & Shen \& Wang, 1991 & Soil & Guangdong, China \\
\hline 58 & S. minutum & Maneesakorn et al., 2010 & Soil & Thailand \\
\hline 59 & S. monticolum & Stock et al., 1997 & Soil & $\begin{array}{l}\text { Gyeongnam Province, Republic } \\
\text { of Korea }\end{array}$ \\
\hline 60 & S. neocurtillae & Nguyen and Smart Jr, 1992 & Neocurtilla hexadactylla (Perty) & LaCrosse, Florida, USA \\
\hline 61 & S. nepalense & Khatri-Chhetri et al., $2011 \mathrm{~b}$ & Soil & Nepal \\
\hline 62 & S. nguyeni & Malan et al., 2016 & Soil & South Africa \\
\hline 63 & S. nyetense & Kanga et al., 2012 & Soil & Cameroon \\
\hline 64 & S. oregonense & Liu and Berry, 1996 & Soil & Oregon, USA \\
\hline 65 & S. pakistanense & Shahina et al., 2001 & Soil & Karachi, Pakistan \\
\hline 66 & S. papillatum & San-Blas et al., 2015 & Soil & Venezuela \\
\hline 67 & S. phyllophagae & Nguyen and Buss, 2011 & Phyllophaga sp. & Florida, USA \\
\hline 68 & S. poinari & Mráček et al., 2014 & Soil & Czech Republic \\
\hline 69 & S. puertoricense & Román and Figueroa, 1994 & Soil & Loiza, Puerto Rico \\
\hline 70 & S. pui & Qiu et al., 2011 & Soil & Yunnan, China \\
\hline 71 & S. puntauvense & Uribe-Lorío et al., 2007 & Soil & Costa Rica \\
\hline 72 & S. pwaniensis & Puza et al., 2017 & Soil & Tanzania \\
\hline 73 & S. ralatorei & Grifaldo-Alcantara et al., 2017 & Soil & Mexico \\
\hline 74 & S. rarum & (de Doucet, 1986) Mamiya, 1988 & Soil & Cordoba, Argentina \\
\hline 75 & S. riobrave & Cabanillas et al., 1994 & Soil & Weslaco,Texas, USA \\
\hline 76 & S. riojaense & Půža et al., 2020 & Soil & La Rioja province, Spain \\
\hline 77 & S. ritteri & de Doucet \& Doucet 1990 & Soil & Córdoba, Argentina \\
\hline 78 & S. robustispiculum & Phan et al., 2005 & Soil & Vietnam \\
\hline 79 & S. sacchari & Nthenga et al., 2014 & Soil & South Africa \\
\hline 80 & S. sangi & Phan et al., 2001a & Soil & Vietnam \\
\hline 81 & S. sasonense & Phan et al., 2006a & Soil & Vietnam \\
\hline 82 & S. scapterisci & Nguyen and Smart Jr, 1990 & Scapteriscus vicinus Scudder & Rivera, Uruguay \\
\hline 83 & S. scarabaei & Stock and Koppenhöfer, 2003 & $\begin{array}{l}\text { Anomala (= Exomala) orientalis } \\
\text { and Popillia japonica }\end{array}$ & New Jersey, USA \\
\hline 84 & S. schliemanni & Spiridonov et al., 2010 & Osmoderma ceremita & Germany, Europe \\
\hline 85 & S. siamkayai & Stock et al., 1998 & Soil & Petchabun Province, Thailand \\
\hline 86 & S. sichuanense & Mráček et al., 2006 & Soil & China \\
\hline
\end{tabular}


Table 1 List of Steinernema species recorded from different countries of the world (Continued)

\begin{tabular}{lllll}
\hline S. no. & Species & Authors \& year & Host insect/soil & Location \\
\hline 87 & S. silvaticum & Sturhan et al., 2005 & Soil & Berlin Germany, Europe \\
88 & S. surkhetense & Khatri-Chhetri et al., 2011b & Soil & Sopal \\
89 & S. tami & Luc et al., 2000 & Soil & Vietnam \\
90 & S. taiwanensis & Tseng et al., 2018 & Soil & Taiwan \\
91 & S. texanum & Nguyen et al., 2007 & Soil & Texas, USA \\
92 & S. thanhi & Phan et al., $2001 \mathrm{~b}$ & Soil & Vietnam \\
93 & S. tielingense & Ma et al., 2012 & Soil & China \\
94 & S. tophus & Çimen et al., 2014 & Soil & South Africa \\
95 & S. unicornum & Edgington et al., 2009a & Soil & Chile \\
96 & S. xinbinense & Ma et al., 2012 & Soil & China \\
97 & S. xueshanense & Mráček et al., 2009 & Soil & China \\
98 & S. weiseri & Mráček et al., 2003 & Soil & Czech Republic, Europe \\
99 & S. yirgalemense & Nguyen et al., 2004b & Soil & Yirgalem, Ethiopia \\
100 & S. bertusi & Katumanyane et al., 2019 & & Tito, Mpumalanga, and \\
& & & Port Edward, Kwa
\end{tabular}

*Species considered as junior synonym, species inquirendae and nomun nudum are mentioned in the text

from a field in the State of São Paulo, Brazil. Some territories of South America are still unexplored for EPNs; however, some of the new species of steinernematids described from here include S. rarum \{(de Doucet, 1986) Mamiya, 1988\} from Argentina, S. ritteri (de Doucet and Doucet, 1990) from Argentina, S. scapterisci (Nguyen and Smart Jr, 1990) from Uruguay, S. colombiense (Lopez-Nunez et al., 2008) from Colombia, S. unicornum
(Edgington et al., 2009a) and S. australe (Edgington et al., 2009b) from Chile, S. brazilense (Nguyen et al, 2010) from Brazil, and S. papillatum (San-Blas et al., 2015) S. goweni (San-Blas, 2016) from Venezuela. Among Heterorhabditis, two new species $H$. amazonensis (Andaló et al., 2006) and H. atacamensis (Edgington et al., 2011) were reported from Brazil and Chile, respectively. Few already described species reported from South America included S. carpocapsae, S.

Table 2 List of Heterorhabditis species recorded from different countries of the world

\begin{tabular}{|c|c|c|c|c|}
\hline S. no. & Species & Authors \& year & Host insect/ soil & Location \\
\hline 1 & H. amazonensis & Andaló et al., 2006 & Soil & Brazil \\
\hline 2 & H. atacamensis & Edgington et al., 2011 & Soil & Chile \\
\hline 3 & H. bacteriophora & Poinar, 1976 & Heliothis punctigera Wallengren & Brecon, South Australia \\
\hline 4 & H. baujardi & Phan et al., 2003 & Soil & Vietnam \\
\hline 5 & H. beicherriana & Li et al., 2012 & Soil & China \\
\hline 6 & H. downesi & Stock et al., 2002 & Soil & Ireland \\
\hline 7 & H. floridensis & Nguyen et al., 2006a & Soil & Florida, USA \\
\hline 8 & H. georgiana & Nguyen et al., 2008b & - & Georgia \\
\hline 9 & H. indica & Poinar Jr et al., 1992 & Soil (Soil baited with Scirpophaga excerptalis Walker, larvae) & Coimbatore, India \\
\hline 10 & H. marelatus & Liu \& Berry, 1996 & Soil & Seaside, Oregon, USA \\
\hline 11 & H. megidis & Poinar Jr et al., 1987 & Popillia japonica Newman & Jeromesville, Ohio, USA \\
\hline 12 & H. mexicana & Nguyen et al., 2004a & Soil & Mexico \\
\hline 13 & H. noenieputensis & Malan et al., 2014 & Soil & South Africa \\
\hline 14 & H. safricana & Malan et al., 2008 & Soil & South Africa \\
\hline 15 & H. taysearae & Shamseldean et al., 1996 & Soil & Egypt \\
\hline 16 & H. zealandica & Poinar, 1990 & Heteronychus arator $\mathrm{F}$. & Auckland, New Zealand \\
\hline
\end{tabular}

*Species considered as junior synonym, species inquirendae and nomun nudum are mentioned in the text 
feltiae, S. scapterisci, and H. bacteriophora (Rosales and Suarez, 1998; Saenz, 1999; Fan et al., 2000).

\section{Europe}

Steinernematids isolated from European countries include S. affine (Bovien, 1937) Wouts et al., 1982 from Denmark, S. kraussei (Steiner, 1923a, b) from Germany, S. carpocapsae (Weiser, 1955) from Czechoslovakia, S. bicornutum (Tallosi et al., 1995) from Serbia (formerly Yugoslavia), S. weiseri (Mráček, et al., 2003) from Czech Republic, S. apuliae (Triggiani et al, 2004) from Italy, S. silvaticum (Sturhan et al., 2005) from Germany, S. ichnusae (Tarasco et al., 2008) from Italy, S. boemarei (Lee et al., 2009) from France, S. schliemanni (Spiridonov et al, 2010) from Germany, S. poinari (Mráček et al., 2014) from Czech Republic and S. riojaense (Půža et al., 2020) from Spain. Among new species of Heterorhabditis, $H$. downesi has been reported from here. Other indigenous species reported from Europe are H. bacteriophora, $H$. indica, $H$. megidis, S. feltiae, S. vulcanicum, S. arenarium, and several undescribed species (Tarasco et al., 2015).

In Europe, the work on EPNs began since early 1980s and the large-scale production of these nematodes started in the year 1986. Currently, three large-scale companies are in operation producing nematodes by in vitro methods, which includes Becker Underwood (UK), e-nema (Germany), and Koppert (The Netherlands). There are also some small-scale producers like Andermatt Biocontrol (Switzerland), Bionema (Swansea, Wales), and Owiplant (Poland). The nematode products commercially used in Europe for insect pest suppression include H. megidis, $H$. bacteriophora, S. feltiae, S. carpocapsae, and S. kraussei. All these products were based on clay, vermiculite or polymer formulations.

\section{Turkey}

Özer et al. (1995) reported S. carpocapsae from the Black Sea region, but later, A.P Reid re-identified this isolate as S. feltiae (Hominick et al., 1996). Among Heterorhabditis, the first nematode species described from Turkey was $H$. bacteriophora detected by Kepenekci et al. (1999) in Aelia population (Aelia rostrata Boh.) collected from Ekecik (Aksaray) winter quarters. Other species of EPNs reported from Turkey included S. feltiae, S. carpocapsae, S. affine, S. websteri, S. anatoliense, S. weiseri, S. bicornutum, S. kraussei, and some undescribed Steinernema species, while among heterohabditids, 3 species viz., $H$. bacteriophora, $H$. marelatus, and $H$. megidis were reported (Kepenekci and Susurluk, 2000; Hazir et al, 2003; Yılmaz et al, 2007; Ünlü et al, 2007; Kepenekci, 2002, 2014; Ertürk et al., 2014; Gökçe et al., 2015; Canhilal et al., 2016, 2017). Hazir et al. (2003) described a new species of Steinernema, S. anatoliense, which was isolated from soil samples collected in the locality of Kars, East
Anatolia, and was later synonymized with S. carpocapsae. However, there is still paucity of information on the diversity of EPN species in Turkey.

\section{Russia}

Ivan N. Filipjev, who is regarded as the founder of modern nematology in Russia was the first to describe S. feltiae (Filipjev, 1934). Galina V. Veremchuk later initiated applied research in EPNs in the AllUnion Plant Protection Institute, St.-PetersburgPushkin and described several steinernematid species, which are considered now as junior synonyms of other steinernematid species (Nguyen and Hunt, 2007). Moreover, other species described from Russia are $S$. arenarium, S. bicornutum, S. kraussei, $S$. feltiae, S. carpocapsae, S. krussie, S. kushidai, $H$. zealandica, $H$. megidis, and $H$. bacteriophora (Ivanova et al., 2000).

The two products of EPNs that are currently marketed in Russia are 'Nemabact' and 'Entonem F', which are suspensions of $S$. carpocapsae and S. feltiae, respectively. Their production and commercialization is regulated by 'Biodan' company in Sankt-Petersburg and 'Biometodika' company in Moscow region.

\section{Africa}

Surveys for isolation of EPNs in Africa include Egypt, Kenya, Ethiopia, Tanzania, Benin, Morocco, South Africa, Rwanda, Algeria, Cameroon, and Nigeria. The species of steinernematids and heterorhabditids described in the past 2 decades are H. bacteriophora, S. arenarium, S. glaseri, S. karii, S. yirgalemense, S. weiserii, $H$. taysearae, and $H$. indica (Waturu et al., 1997; Waturu, 1998; Mwaniki et al., 2008; Stack et al., 2000) from Kenya; S. yirgalemense, $S$. ethiopiense, and H. bacteriophora (Nguyen et al., 2004b; Mekete et al., 2005; Tamirou et al., 2012) from Ethiopia; S. cameroonense, S. nyetense, $H$. baujardi, and $H$. amazoniensis from Cameroon (Kanga et al., 2012); S. khoisanae, S. citrae, S. sacchari, S. tophus, S. innovationi, S. jeffreyense, S. beitlechemi, S. fabii, S. nguyeni, S. biddulphi, S. litchii, S. yirgalemense, $H$. bacteriophora, $H$. safricana, and $H$. noenieputensis (Nguyen et al., 2006a, b; Malan et al., 2011; Nthenga et al., 2014; Çimen et al., 2014; Çimen et al., 2015; Malan et al., 2015; Çimen et al., 2016; Hatting et al., 2009; Abate et al., 2016; Malan et al., 2016; Steyn et al., 2017; Malan et al., 2008; Malan et al., 2014) from South Africa; S. feltiae and $H$. bacteriophora (Tarasco et al., 2009; Zamoum et al., 2011) from Algeria; Steinernema sp, $H$. sonorensis, and $H$. indica (Zadji et al., 2013; Houssou et al., 2014) from Benin; S. feltiae from Morocco (Akalach and Wright, 1995) and Nigeria (Akyazi et al., 2012); S. carpocapsae and $H$. 
bacteriophora from Rwanda (Yan et al., 2016) and $S$. pwaniensis (Puza et al., 2017) from Tanzania.

\section{Egypt}

In Egypt, the initial research on EPN began in the 1970s when Dr. El-Kifl worked on the biological control potential of Neoaplectana (= Steinernema) carpocapsae against the cotton leaf worm, Spodoptera littoralis, one of the most economically important insect pests in Egypt. The surveys carried out in Egyptian soils revealed that species of heterorhabditids were more prevalent than steinernematids; however, research regarding their use to control other insect species was done as well. Steinernematids recorded from Egypt included S. abbasi, S. carpocapsae, S. arenarium, S. kushidai, and S. glaseri (Abd-Elbary et al., 2012), whereas heterorhabditids included $H$. bacteriophora, $H$. indica (Abd-Elgawad and Nguyen, 2007), H. baujardi (Abd El-Rahman, 2006), and H. egyptii (Abd-Elgawad and Ameen, 2005). $H$. taysearae is a new species from the soils of Egypt; however, H. egyptii is currently included in species inquirendae (Subbortin and Hunt, 2007). Many other heterorhabditids and some steinernematids have been isolated from Egyptian soils but yet to be identified (Abd-Elgawad et al., 2013).

\section{Asia}

\section{India}

In India, the initial research on EPN was conducted primarily with exotic species/strains of $S$. carpocapsae, $S$. glaseri, S. feltiae, and H. bacteriophora imported by researchers. However, when applied in field conditions for control of insect pests, inconsistent results were observed probably due to their poor adaptability to the local agro-climatic conditions. Apart from this, it was also believed that exotic EPN introduction may lead to a negative impact on non-target organisms (Kaya et al., 2006), which will be commeriorated (commercialized) by the isolation of indigenous nematode isolates which serve as a valuable resource, not only from a biodiversity perspective but also from an environmental perspective due to their adaptability and utility in biological control. Therefore, a search for indigenous species/strains resulted in a number of nematode isolates from different parts of India (Ganguly, 2003). Fifteen species including 12 steinernematids and 3 heterorhabditids have been reported from India, of which only one new species, Heterorhabditis indica (Poinar Jr et al., 1992), was described. Among steinernematids, no new species have been reported till date, but the three previously described new species have been synonymized with existing ones viz., Steinernema thermophilum (Ganguly and Singh, 2000) synonymized with $S$. abbasi (Elawad et al., 1997), S. meghalayense (Ganguly et al., 2011) synonymized with S. carpocapsae (Weiser, 1955) Wouts et al.,
1982, and S. dharanai (Kulkarni et al., 2012) was recognized as a junior synonym of $S$. hermaphroditum Stock et al., 2004 (Hunt, 2007). The other steinernematid species reported from India are S. bicornutum Tallosi, Peters and Ehlers (Hussaini et al., 2001), S. riobrave Cabanillas, Poinar and Raulston (Ganguly et al., 2002), S. glaseri Steiner (Kadav and Lalramliana, 2012), S. carpocapsae Weiser (Hussaini et al., 2001), S. tami Luc, Nguyen, Reid and Spiridonov (Hussaini et al., 2001), S. siamkayai Stock, Somsook and Reid (Ganguly et al., 2002), S. feltiae (Filipjev, 1934) Wouts et al., 1982 (Ganguly and Sosamma, unpublished data), S. sangi Phan, Nguyen and Moens (Lalramnghaki et al., 2017), S. surkhetense Khatri-Chhetri,Waeyenberge, Spiridonov, Manadhar and Moens (Bhat et al., 2017), S. pakistanense Shahina, Anis, Reid, Rowe and Maqbool (Bhat et al., 2018), S. cholashanense Nguyen et al., 2008a (Mhatre et al., 2018), and S. hermaphroditum (Bhat et al., 2019). Other indigenous isolates described from India included S. feltiae and S. riobrave but there is no authentic data of these two and they are simply described on few morphometrical characters which are not valid proof of their existence in India. Few others were previously described as new species like $S$. masoodi, S. seemae, S. qazi, and S. sayeedae (Ali et al., 2005, 2009, 2010 and Ali and Azra, 2011) but all these provide poor and inaccurate descriptions and hence were regarded as species inquirendae by Hunt (2007). Ali et al. (2010), provided molecular sequencing data of $S$. masoodi and S. seemae which when analyzed revealed that these sequences do not belong to entomoparasitic nematodes (Hunt and Subbotin, 2016). From these data, it is clear that $S$. masoodi and $S$. seemae are still not molecularly characterized and remain as species inquirendae.

Among Heterorhabditis, three indigenous nematode species have been reported of which $H$. indica Poinar Jr et al. (1992) only new species is described from India till date. The other two indigenous species from India include $H$. bacteriophora Poinar (Bhat et al., 2020) and H. baujardi Phan, Subbotin, Nguyen and Moens (Vanlalhlimpuia and Lalramnghaki, 2018).

\section{China}

In China, the work on EPNs started during mid-1980s and early 1990s in collaboration with some institutes of Australia and Guangzhou (Bedding, 1990). Some new species of steinernematids described from China include S. caudatum (Xu et al., 1991), S. longicaudum (Shen and Wang, 1992), S. ceratophorum (Jian et al., 1997), S. guangdongense (Qiu et al. 2004), S. aciari (Qiu et al., 2005a), S. akhursti (Qiu et al., 2005b), S. beddingi (Qiu et al., 2005c), S. leizhouense (Nguyen et al., 2006b), S. sichuanense (Mráček et al., 2006), S. 
hebeiense (Chen et al., 2006), S. cholashanense (Nguyen et al., 2008a), S. xueshanense (Mráček et al., 2009), S. pui (Qiu et al., 2011), S. changbaiense (Ma et al., 2012a), S. tielingense (Ma et al., 2012b) and S. xinbinense (Ma et al., 2012a, b, c). Among heterorhabditids, one new species, $H$. beicherriana ( $\mathrm{Li}$ et al., 2012) were recorded. Some other already described species of Steinernematidae identified from China include S. litorale, S. silvaticum, S. feltiae, S. bicornutum, S. affine, S. riobrave, S. yirgalemense, S. kushidai, S. scapterisci, S. carpocapsae, S. ritteri, S. tami, S. rarum, and $S$. sasonense and those of Heterorhabditidae are $H$. megidis, $H$. zealandica, $H$. brevicaudis, $H$. indica, and $H$. baujardi (Wang et al., 2014).

China has also made advances in in vitro solid production of EPNs and produced several species of EPNs using solid cultures which were based on the lower labor cost, improved media and mechanization process (Han et al., 1995; Han and Ehlers, 1988). Century Horse Development Ltd. named company under the guidance of Guangdong Entomological Institute currently is involved in EPN commercialization for field trials in China and for internal and international markets. The work on EPN for controlling quarantine pests is still in progress.

\section{Pakistan}

In Pakistan, the research studies on EPNs was started by Shahina and Maqool in 1996. The intense interest in the use of EPNs for biological control resulted in exploration for new species. Two new species $S$. pakistanense (Shahina et al., 2001) and S. asiaticum (Anis et al., 2002) have been described from Pakistan. Among Heterorhabditis, H. pakistanense (Shahina et al., 2016) was described new species from Pakistan which was later synonymized with $H$. indica (Hunt and Subbotin, 2016). The other already described species reported from the country include $S$. abbasi, S. siamkayai, S. feltiae, S. cholashanense, S. affine, $S$. carpocapsae, S. litorale, H. bacteriophora, and H. indica (Shahina and Salma, 2010; Tabassum et al., 2017).

\section{Iran}

Initial surveys conducted for the isolation of EPNs led to the discovery of several known or new species. Parvizi et al. (unpublished) reported $S$. arenarium and $H$. bacteriophora as natural pathogens of Agrotis ipsilon from West Azerbaijan province. Tanha maafi et al. (2006) isolated S. feltiae from soils of Mazandaran and Tehran provinces. A new species $S$. arasbaranense (Nikdel et al., 2011) was described from East Azerbaijan province. Other surveys resulted in some already described species viz., $S$. glaseri, S. carpocapsae, S. bicornutum, S. kraussei (Karimi et al., 2009; Kary et al., 2009; Nikdel et al., 2008, 2010; Ebrahimi and Niknam, 2011; Nikdel and Niknam, 2015; Rahatkhah et al., 2015).

\section{Thailand}

Surveys conducted in Thailand have revealed some new and already described species of both steinernematids and heterorhabditids. Some of the newly described species from agricultural soils are S. siamkayai (Stock et al., 1998) and S. minutum (Maneesakorn et al., 2010). The other already described species reported from the country are $H$. bacteriophora, $H$. baujardi, $H$. indica, $S$. khoisanae, and S. websteri (Thanwisai et al., 2012). Species of EPNs including S. siamkayai, S. minutum, S. khoisanae, S. scrabaei, S. kushidai, H. indica, $H$. bacteriophora, H. baujardi, H. somsookae (synonymized with $H$. baujardi), $H$. gerradi (synonymized with $H$. indica), and $H$. zealandica are commonly found species of entomopathogenic nematodes in Thailand (Thanwisai, et al., 2012; Maneesakorn et al., 2015; Yooyangket et al., 2018).

\section{Japan}

S. kushidai (Mamiya, 1988), S. litorale (Yoshida, 2005), and S. ashiuense (Phan et al., 2006b) are new species first described from Japan. Some of the already described species reported from Japan are H. indica, H. megidis, $S$. carpocapsae, S. feltiae, and several undescribed steinernematids (Yoshida et al., 1998).

\section{Vietnam}

Surveys carried out in Vietnam revealed the presence of already described and some new species. S. tami (Luc et al., 2000), S. loci (Phan et al., 2001a), S. sangi (Phan et al., 2001a), S. thanhi (Phan et al., 2001b), S. robustispiculum (Phan et al., 2005), S. backanense (Phan et al., 2006a, b), S. cumgarense (Phan et al., 2006a, b), S. eapokense (Phan et al., 2006a, b), S. sasonense (Phan et al., 2006a, b), and S. huense (Phan et al., 2014) are some species of Steinernematids recorded from Vietnam. Among heterorhabditids, $H$. baujardi (Phan et al., 2003) has been found new to this country. The other locally described species include S. siamkayai, $H$. bacteriophora, $H$. indica, and H. megidis (Phan et al., 2003).

\section{Korea}

Extensive surveys by research workers led to the isolation of several steinernematids and heterorhabditids viz., S. carpocapsae, S. glaseri, S. longicaudum, S. intermedia, S. feltiae, H. bacteriophora, and H. megidis (Choo et al., 1995; Hang et al., 2007; Lee et al., 2002). Moreover, one new species $S$. monticolum was isolated from soils of Gyeongnam Province (Stock et al., 1997).

\section{Nepal}

Surveys conducted for determining the EPN diversity from Nepal resulted in isolation of $S$. abbasi, $S$. 
cholashanense, S. feltiae, S. siamkayai, and H. indica (Khatri-Chhetri et al., 2010). Some new species reported from Nepal are $S$. nepalense, $S$. surkhetense, $S$. lamjungense, and $S$. everestense (Khatri-Chhetri et al., 2011a, b).

\section{Jordan}

The first survey to record the presence and distribution of steinernematids and heterorhabditids and their associated bacteria in Jordan was done by Stock et al. (2008). Four EPN species including three Steinernema and one Heterorhabditis were recovered. These include S. anatoliense, S. carpocapsae, S. feltiae, and $H$. bacteriophora.

\section{Sultanate of Oman}

There is no available data regarding diversity of EPNs from Oman except S. abbasi (Elawad et al., 1997), which was identified and described as a new species from this country. This species was isolated by Dr. Mohamed S. Abbas (Elawad et al., 1996) from soil of alfalfa fields located at Agricultural Research Station near Salalah in the south of the Sultanate of Oman.

\section{United Arab Emirates}

Surveys carried out in United Arab Emirates (UAE) revealed the isolation of $S$. abbasi and H. bacteriophora from adults of the red palm weevil, Rhynchophorus ferrugineus and from the soil of a palm orchard and a clover field (Abbas et al., 2001a), S. riobrave from larvae of Spodoptera exigua infesting clover and H. bacteriophora from the soil of a clover field (Abbas et al., 2001b).

\section{Kingdom of Saudi Arabia}

Saleh and Alheji (2003) isolated H. indica from the soil in the Eastern province of Saudi Arabia.

\section{Australia}

Surveys were conducted for about 10 years in all states and territories of Australia for isolation of EPNs (Akhurst and Bedding, 1986). Steinernematids recorded during the survey were $S$. bibionis (synonymized with $S$. feltiae), S. feltiae, S. glaseri, S. kraussei, and S. longicaudum and those of heterorhabditids were $H$. zealandica and $H$. bacteriophora (Wouts et al. 1982; Akhurst and Bedding, 1986). All these species were described by Akhurst and Bedding (1986) using morphological examination and cross-breeding studies. Some of the species previously reported have either been synonymized or included as species inquirendae.

\section{New Zealand}

Very few surveys have been conducted for predicting the EPN biodiversity in New Zealand and therefore not much information is available from this country. Ali and Wharton (2017) carried out investigation for the presence of entomopathogenic nematode in Otago region in the South Island of New Zealand and reported the occurrence of S. kraussei and S. feltiae. H. zealandica has also been reported from soils of Waikato pasture.

\section{Conclusions}

Entomopathogenic nematodes (EPNs) have been searched from almost all the continents with the exception of Antarctica. Further surveys are required to include additional geographic areas and climatic conditions, both in plantations and forest areas with an aim to identify native additional EPN species. The native species and populations of EPNs may prove a valuable resource, not only from a biodiversity perspective but also from an environmental perspective because of their adaptability to local environmental conditions. Besides, their virulence and recycling potential within the host may also be higher. Utilization of native EPN species would serve as an alternative to chemical pesticides and fit well in integrated pest management program.

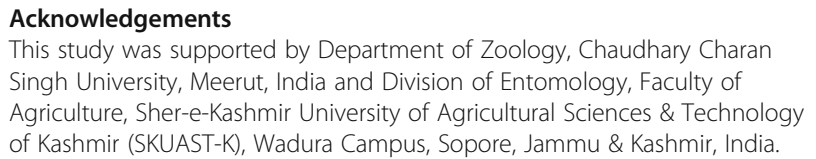

\section{Availability of data and materials}

Data collected from different sources during this study are included in this article.

\section{Authors' contributions}

The first author, AHB collected the information mentioned in the tables, under subheadings of the manuscript and summarized the data related to different countries under various subheadings. The second author, AKC edited the paper and removed errors and grammatical mistakes. The third author, THA prepared abstract and introduction part of the manuscript and made necessary corrections. All authors read and approved the final manuscript.

\section{Authors' information}

Aashaq Hussain Bhat is DST Inspire Fellow and Guest Faculty at Department of Zoology, Chaudhary Charan Singh University, Meerut, India. Ashok Kumar Chaubey is Professor at Department of Zoology, Chaudhary Charan Singh University, Meerut, India. Tarique Hassan Askary is Assistant Professor at Division of Entomology, Faculty of Agriculture, Sher-e-Kashmir University of Agricultural Sciences \& Technology of Kashmir (SKUAST-K), Wadura Campus, Sopore, Jammu \& Kashmir, India.

\section{Funding}

AHB is thankful to Department of Science and Technology, New Delhi, India for providing finiancial assistance through DST Inspire Fellowship/2014/76.

Ethics approval and consent to participate

Not applicable

Consent for publication

Not applicable

Competing interests

The authors declare that they have no competing interests. 


\section{Author details}

${ }^{1}$ Nematology Laboratory, Department of Zoology, Chaudhary Charan Singh University, Meerut 250004, India. ${ }^{2}$ Division of Entomology, Faculty of Agriculture, Sher-e-Kashmir University of Agricultural Sciences \& Technology of Kashmir, Wadura Campus, Sopore, Jammu \& Kashmir 193201, India.

Received: 7 October 2019 Accepted: 26 January 2020

Published online: 23 March 2020

\section{References}

Abate BA, Malan AP, Tiedt LR, Wingfield MJ, Slippers B, Hurley BP (2016) Steinernema fabii n. sp. (Rhabditida: Steinernematidae), a new entomopathogenic nematode from South Africa. Nematol 18:235-255

Abbas MST, Hanounik SB, Mousa SA, Awash SA (2001b) Isolation of entomopathogenic nematodes from Ras Al-Khima and Al-Fugaira Emirates (UAE). Egyp J Biol Pes Cont 11:191

Abbas MST, Hanounik SB, Mousa SA, Mansour MI (2001a) On the pathogenicity of Steinernema abbasi and Heterorhabditis indicus isolated from adult, Rhynchophorus ferrugineus. Intern J Nematol 11:69-72

Abd El-Rahman RM (2006) Isolation and identification of Heterorhabditis baujardi as a first record from Egypt and studying some of its biological traits. Egyp J Ap Sci 8:298-307

Abd-Elbary NA, Shamseldean MSM, Stock SP, Abu-Shady NM (2012) Diversity of entomopathogenic nematode species (Heterorhabditidae and Steinernematidae) in Egypt. Egyp J Agronem 11:333-353

Abd-Elgawad MMM, Ameen HH (2005) Heterorhabditis egyptii n. sp. (Rhabditida: Heterorhabditidae) from Egypt. Egyp J Agril Res 2:855-870

Abd-Elgawad MMM, Jian H, Qiao Y, Hammam MMA (2013) Entomopathogenic nematodes and their potential against insects and phytonematodes in Egypt. In: Pridannikov MV, Udalova ZV, Butorina NN (eds) Proceedings of the 10th International Nematological Symposium. Russian Society of Nematologists, Golitsyno - Bolshie Vyazemy, Moscow, Russia, pp 98-101

Abd-Elgawad MMM, Nguyen KB (2007) Isolation, identification and environmental tolerance of new heterorhabditid populations from Egypt. Int J Nematol 17: 116-123

Akalach M, Wright DJ (1995) Control of the larvae of Conorhynchus mendicus (Col.: Curculionidae) by Steinernema carpocapsae and Steinernema feltiae (Nematoda: Steinernematidae) in the Gharb area (Morocco). Entomophaga 40:321-327

Akhurst R, Bedding RA (1986) Natural occurrence of insect pathogenic nematodes (Steinernematidae and Heterorhabditidae) in soil in Australia. J Aus Ent Soc 25:241-244

Akyazi F, Ansari MA, Ahmed Bl, Crow WT, Mekete T (2012) First record of entomopathogenic nematodes (Steinernematidae and Heterorhabditidae) from Nigerian soil and their morphometrical and ribosomal DNA sequence analysis. Nematolog Med 40:95-100

Ali F, Wharton DA (2017) A survey of entomopathogenic nematodes from Otago, New Zealand, with the first record of Steinernema kraussei (Steiner, 1923) (Rhabditida: Steinernematidae) from the Southern Hemisphere. NZ J Zool 44:245-255

Ali SS, Azra S (2011) Steinernema sayeedae sp. n. a heat tolerant EPN from banana rhizosphere of Koshambhi district, U.P. India. Trends Biosci 4:123-125

Ali SS, Riyaz A, Verma V, Azra S, Pervez R, Sobia A (2010) Molecular characterization of Steinernema masoodi, S. seemae and other Indian isolates of Steinernema spp. Trends Biosci 3:112-116

Ali SS, Shaheen A, Asif M, Akhtar MH (2009) Steinernema qazii sp. n. (Nematoda: Steinernematidae) from Kanpur, India. Trends Biosci 2:59-64

Ali SS, Shaheen A, Pervez R, Hussain MA (2005) Steinernema masoodi sp. n. and S. seemae sp. n. (Nematoda: Rhabditidae [sic]: Steinernematidae) from India. Int J Nematol 15:89-99

Alia M, Escuer M, Campos R (2002) Desarrollo de estrategias de control integrado de Agriotes spp. (Coleoptera, Elateridae) en el cultivo de patata. Subproyecto III: Utilidad de los nematodos entomopatogenos en el control de Agriotes spp. (Coleoptera, Elateridae) en el cultivo de la patata. INIA.CCAA, RTA03-004C4-4. 2002-2005

Artyukhovsky AK, Kozodoi EM, Reid AP, Spiridonov SE (1997) Redescription of Steinernema arenarium (Artyukhvsky, 1967) topotypes from Central Russia and a proposal for S. anomale (Kozodoi, 1984) as a junior synonym. Russian J Nemat 5:31-37

Andaló V, Nguyen KB, Moino A (2006) Heterorhabditis amazonensis n. sp. (Rhabditida: Heterorhabditidae) from Amazonas, Brazil. Nem 8:853-867
Anis M, Shahina F, Reid AP, Rowe J (2002) Steinernema asiaticum sp. n. (Rhabditida: Steinernematidae) from Pakistan. Int J Nematol 12:220-231

Askary TH (2010) Nematodes as biocontrol agents. In: Lichtfouse E (ed) Sociology, organic farming, climate change and soil science. Springer, The Netherlands, pp 347-378

Askary TH, Abd-Elgawad MMM (2017) Beneficial nematodes in agroecosystem: A global perspective. In: Abd-Elgawad MMM, Askary TH, Coupland J (eds) Biocontrol Agents: entomopathogenic and slug parasitic nematodes. CAB International, pp 3-25

Bedding RA (1990) Logistics and strategies for introducing entomopathogenic nematode technology in developing countries. In: Gaugler R, Kaya HK (eds) Entomopathogenic Nematodes for Biological Control. CRC Press, Boca Raton, pp 233-248

Bhat AH, Aksary TH, Ahmad MJ, Aasha, Suman, Chaubey AK (2020) Description of Heterorhabditis bacteriophora (Nematoda: Heterorhabditidae) isolated from hilly areas of Kashmir Valley. Egyp J Biol Pest Cont 29. In press. https://doi. org/10.1186/s41938-019-0197-6

Bhat AH, Chaubey AK, Pưža V (2018) The first report of Xenorhabdus indica from Steinernema pakistanense: co-phylogenetic study suggests co-speciation between $X$. indica and its steinernematid nematodes. J. Helmin 92:1-10

Bhat AH, Chaubey AK, Shokoohi E, Mashela PW (2019) Study of Steinernema hermaphroditum (Nematoda, Rhabditida), from the West Uttar Pradesh, India. Acta Parasitol 64:727-737 https://doi.org/10.2478/s11686-019-00061-9

Bhat AH, Istkhar CAK, Püža V, San-Blas E (2017) First report and comparative study of Steinernema surkhetense (Rhabditida: Steinernematidae) and its symbiont bacteria from subcontinental India. J Nematol 49:92-102

Bovien P (1937) Some types of association between nematodes and insects. Videnskabelige Meddelelser fra Dansk Naturhistorisk Forening, København 101:1-114

Cabanillas HE, Poinar GO Jr, Raulston JR (1994) Steinernema riobravis n. sp. (Rhabditida: Steinernematidae) from Texas. Fund App Nematol 17:123-131

Canhilal R, Waeyenberge L, Toktay H, Bozbuga R, Çetintas R, Imren M (2016) Distribution of Steinernematids and Heterorhabditids (Rhabditida: Steinernematidae and Heterorhabditidae) in the southern Anatolia region of Turkey. Egyp J Biol Pest Cont 2 6:1-6

Canhilal R, Waeyenberge L, Yuksel E, Koca AS, Deniz Y, Imren M (2017) Assessment of the natural presence of entomopathogenic nematodes in Kayseri soils, Turkey. Egyp J Biol Pest Cont 27:237-244

Chen S, Yan A, Li X, Moens M, Spiridonov S (2006). A new entomopathogenic nematode, Steinernema hebeiense sp. n. (Rhabditida: Steinernematidae), from North China. Nematol 8:563-574. https:/doi.org/10.1163/156854106778614056

Choo HY, Kaya HK, Stock SP (1995) Isolation of entomopathogenic nematodes (Steinernematidae and Heterorhabditidae) from Korea. Jap J Nematol 25:44-51

Çimen H, Lee MM, Hatting J, Hazir S, Stock SP (2014) Steinernema tophus sp n. (Nematoda: Steinernematidae), a new entomopathogenic nematode from South Africa. Zootaxa 3821:337-353

Çimen H, Lee MM, Hatting J, Hazir S, Stock SP (2015) Steinernema innovationi n. sp. (Panagrolaimomorpha: Steinernematidae), a new entomopathogenic nematode species from South Africa. J Hel 89:415-427

Çimen H, Puza V, Nermut J, Hatting J, Ramakuwela T, Faktorova L, Hazir S (2016) Steinernema beitlechemi n. sp., a new entomopathogenic nematode (Nematoda: Steinernematidae) from South Africa. Nematol 18:439-453

Cortez-Madrigal H, Morales-Salvador P, Adams B (2003) Primer registro en Mexico del nematodo Heterorhabditis indicus Poinar. In: Vazquez-Garcia M, Perez DomÂ' nguez, JF, Ibarra-Cortes, K, BalpuestaLeon C, Vazquez-Reyes R, Cervantes-Rios J, Ibarra-Frias, N (eds) Memorias del XXVI Congreso Nacional de Control Biológico. Sociedad Mexicana de Control Biológico, Texcoco, México, pp 68-70.

de Doucet MMA (1986) A new species of Neoaplectana Steiner, 1929 (Nematoda: Steinernematidae) from Cordoba. Arg Rev Nematol 9:317-323

de Doucet MMA, Doucet ME (1990) Steinernema ritteri n. sp. (Nematoda: Steinernematidae) with a key to the species of the genus. Nematolog 36:257-265

Diaz-Mederos P, Najera-Rincon MB, Lezama-Gutierrez R, Rebolledo-Dominguez O, Flores-Lopez HE (2002) Hongos (Hyphomycetes) y nematodos (Nematoda: Heterorhabditidae) entomopatogenos de gallinas ciegas (Coleoptera: Melolonthidae), en Los Altos de Jalisco, Mexico. In: Baez-Sañudo R, JuveraBracamontes JJ (eds) Memorias Del XXV Congreso Nacional de Control Biológico. Sociedad Mexicana de Control Biológico, Texcoco, Mexico, pp 236-238

Dutky SR (1959) Insect microbiology. Adv App Micr 1:175-200

Ebrahimi L, Niknam GH (2011) Detection of thermal preference range of two endemic isolates of entomopathogenic nematodes, Steinernema feltiae 
(Steinernematidae, Tylenchina) and Heterorhabditis bacteriophora (Heterorhabditidae, Rhabditina) for application in biological control of insect pests. J Sustain Agri Product Sci 21:77-86

Edgington S, Buddie AG, Moore D, France A, Merino L, Hunt DJ (2011) Heterorhabditis atacamensis n. sp. (Nematoda: Heterorhabditidae), a new entomopathogenic nematode from the Atacama Desert, Chile. J Helmin 85: 381-394

Edgington S, Buddie AG, Tymo L, France A, Merino L, Hunt DJ (2009a) Steinernema unicornum sp. n. (Panagrolaimomorpha: Steinernematidae), a new entomopathogenic nematode from Chile. J N Morph Syst 12:113-131

Edgington S, Buddie AG, Tymo L, Hunt DJ, Nguyen KB, France Al, Merino LM, Moore D (2009b) Steinernema australe n. sp. (Panagrolaimomorpha: Steinernematidae), a new entomopathogenic nematode from Isla Magdalena, Chile. Nematol 11:699-717

Ehlers R-U (2001) Mass production of entomopathogenic nematodes for plant protection. App Micr Biotech 56:623-633

Elawad SA, Abbas MS, Hague NGM (1996) The establishment, reproduction and pathogenicity of a new species of Steinernema from the Sultanate of Oman in Galleria mellonella. Afro-Asian J Nematol 6:40-45

Elawad SA, Ahmad W, Reid A (1997) Steinernema abbasi sp. n. (Nematoda: Steinernematidae) from the Sultanate of Oman. F App Nematol 20:433-442

Ertürk Ö, Ustaoğlu F, Akyazı F (2014) Occurrence and distribution of entomopathogenic nematodes (Steinernematidae and Heterorhabditidae) in Ordu Province, Turkey. Türk Tarım ve Doğa Bilimleri Dergisi 1:469-480

Fan XJ, Maggiorani A, Gudino S (2000) Uso de nematodos entomopatogenos como una alternativa en el control de polilla (Tecia solanivora), importante plaga de la papa (Solanum tuberosum). Rev For Venez 34:115-118

Filipjev IN (1934) Miscellanea Nematologica 1. Eine neue Art der Gattung Neoaplectana Steiner nebst Bermerkungen über die systematische Stellung der letzteren. Parazitologich 4:229-240

Friedman M (1990) Commercial production and development. In: Gaugler R, Kaya HK (eds) Entomopathogenic nematodes in biological control. CRC Press, Boca Raton, pp 153-172

Ganguly S (2003) Taxonomy of entomopathogenic nematodes and work done in India. In: Hussaini SS, Rabindra RJ, Nagesh M (eds) Current Status of Research on Entomopathogenic Nematodes in India. ICARPDBC, Bangalore, pp 69-108

Ganguly S, Rathore KS, Sushil K, Singh M (2011) Steinernema meghalayensis sp. n. (Rhabditida: Steinernematidae) from northeastern hilly region of India. I J Nematol 41:83-97

Ganguly S, Singh LK (2000) Steinernema thermophilum sp. n. (Rhabditida: Steinernematidae) from India. Int J Nematol 10:183-191

Ganguly S, Singh M, Lal M, Singh LK, Vyas RV, Patel DJ (2002) New record of an entomopathogenic nematode, Steinernema riobrave Cabanillas, Poinar and Raulston, 1994 from Gujarat, India. I J Nematol 32:223

Gaugler R, Han R (2002) Production technology. In: Gaugler R (ed) Entomopathogenic Nematology. CAB International, UK, pp 289-310

Gaugler R, James F, Sen C, Edwin SE, Lewis E (1992) Large-scale inoculative releases of the entomopathogenic nematode Steinernema glaseri: assessment 50 years later. Biol Cont 2:181-187

Georgis R (2002) The Biosys experience: an insider's perspective. In: Gaugler R (ed) Entomopathogenic nematology. CAB International, UK, pp 357-372

Georgis R, Koppenhöfer AM, Lacey LA, Bélair G, Duncan LW, Grewal PS, Samish M, Tan L, Torr P, van Tol RWHM (2006) Successes and failures in the use of parasitic nematodes for pest control. Bio Cont 38:103-123

Glazer RW, Fox H (1930) A nematode parasite of the Japanese beetle (Popillia japonica Newm.). Sc 71:16-17

Gökçe C, Erba GZ, Yılmaz H, Demirbağ Z, Demir Ġ (2015) A new entomopathogenic nematode species from Turkey, Steinernema websteri (Rhabditida: Steinernematidae) and its virulence. Turk J Biol 39:167-174

Gorgadze O, Fanelli E, Lortkhipanidze M, Troccoli A, Burjanadze M, Tarasco E, Luca FD (2018) Steinernema borjomiense n. sp. (Rhabditida: Steinernematidae), a new entomopathogenic nematode from Georgia. Nematol 20:653-669

Grifaldo-Alcantara PF, Alatorre-Rosas R, Segura-León O, Hernandez-Rosas F (2017) Steinernema ralatorei n.sp. isolated from sugarcane areas at Veracruz, Mexico. Southwestern Entomologist 42:171-190. https://doi.org/10.3958/059.042.0117

Han R, Pang X, Li L (1995) Optimization of the medium composition for the solid culture of entomopathogenic Steinernema and Heterorhabditis nematodes. Nat Enem Insec 17:153-164
Han RC, Ehlers RU (1988) Cultivation of axenic Heterorhabditis spp. dauer juveniles and their response to non-specific Photorhabdus luminescens food signals. Nematologica 44:425-435.

Hang TD, Lee DW, Lee SM, Choo HY, Kaya HK, Park CG (2007) Temperature effects on Korean entomopathogenic nematodes, Steinernema glaseri and S. longicaudum, and their symbiotic bacteria. J Microbiol Biotech 17:420-427

Hatting J, Stock SP, Hazir S (2009) Diversity and distribution of entomopathogenic nematodes (Steinernematidae, Heterorhabditidae) in South Africa. J Inver Path 102:120-128

Hazir S, Kaya HK, Stock SP, Keskin N (2003) Entomopathogenic nematodes (Steinernematidae and Heterorhabditidae) for biological control of soil pests. Turk J Nem 27:181-202

Hominick WM (2002) Biogeography. In: Gaugler R (ed) Entomopathogenic nematology. CAB International, UK, pp 115-143

Hominick WM, Reid AP, Bohan DA, Briscoe BR (1996) Entomopathogenic nematodes: biodiversity, geographical distribution and the convention on biological diversity. Biocont Sci and Tech 6:317-332

Houssou GF, Baimey H, Zadji L, de Sutter N, Waeyenberge L, Afouda L, Viane N, Moens M, Decraemer W (2014) Taxonomic study of entomopathogenic nematodes (Nematoda: Steinernematidae, Heterorhabditidae) from Benin. Agron Afric 26:231-245

Hunt DJ (2007) Overview of taxonomy and systematics. In: Nguyen KB, Hunt DJ (eds) Entomopathogenic nematodes: systematics, phylogeny and bacterial symbionts. Nematology Monographs and Perspectives 5. Brill, Leiden, The Netherlands, pp 27-57

Hunt DJ, Nguyen KB (2016) Advances in entomopathogenic nematode taxonomy and phylogeny.Nematology Monographs and Perspectives12. Brill, The Netherlands, p 438

Hunt DJ, Subbotin SA (2016) Taxonomy and systematics. In: Hunt DJ, Nguyen KB (eds) Advances in entomopathogenic nematode taxonomy and phylogeny. Nematology Monographs and Perspectives 12. Brill, The Netherlands, pp 13-58

Hussaini SS, Ansari MA, Ahmad W, Subbotin SA (2001) Identification of some Indian populations of Steinernema species (Nematoda) by RFLP analysis of ITS region of rDNA. Int J Nematol 11:73-76

Ivanova TI, Danilov L, Ivakhnenko OA (2000) Distribution of entomopathogenic nematodes of the families Steinernematidae and Heterorhabditidae in Russia and their morphological characteristics. Paraz 34:323-334

Jian B, Reid AP, Hunt DJ (1997) Steinernema ceratophorum n. sp. (Nematoda: Steinernematidae) a new entomopathogenic nematode from northeast China. Systematic Parasitol 37:115-125

Kadav A, Lalramliana (2012) Efficacy of indigenous entomopathogenic nematodes from Meghalaya, India against the larvae of taro leaf beetle Aplosonyx chalybaeus (Hope). J Par Dis 36:149-154

Kanga FN, Waeyenberge L, Hauser S, Moens M (2012) Distribution of entomopathogenic nematodes in Southern Cameroon. J Inver Path 109:41-51

Karimi J, Kharazi-pakdel A, Yoshiga T, Koohi-habibi M (2009) First Report of Steinernema glaseri (Rhabditida: Steinernematidae) from Iran. Russ J Nematol 17:83-85

Kary NE, Niknam GH, Griffin CT, Mohammadi SA, Mohammadi M (2009) A survey of entomopathogenic nematodes of the families Steinernematidae and Heterorhabditidae (Nematoda: Rhabditida) in the North-West of Iran. Nematol 11:107-116

Katumanyane A, Malan AP, Tiedt LR, Hurley BP (2019) Steinernema bertusi n. sp. (Rhabditida: Steinernematidae), a new entomopathogenic nematode from South Africa. Nematol. https://doi.org/10.1163/15685411-00003309

Kaya HK, Aguillera MM, Alumai A, Choo HY, De la Torre M, Fodor A, Ganguly S, Hazir S, Lakatos T, Pye A (2006) Status of entomopathogenic nematodes and their symbiotic bacteria from selected countries or regions of the world. Bio Cont 38:134-155

Kaya HK, Gaugler R (1993) Entomopathogenic nematodes. Ann Rev Ent 38:181-206

Kepenekci I (2002) Entomopathogenic nematodes (Rhabditida) in the Mediterranean Region of Turkey. Nematolog Med 30:13-15

Kepenekci I (2014) Entomopathogenic nematodes (Steinernematidae, Heterorhabditidae: Rhabditida) of Turkey. Pak J Nematol 32:56-65

Kepenekci İ, Babaroğlu NE, Öztürk G, Halıcı S (1999) Türkiye için yeni bir Entomopatojen nematod Heterorhabditis bacteriophora Poinar 1976 (Rhabditida: Heterorhabditidae). 4. Biyolojik Mücadele Kongresi, Adana, 587-596

Kepenekci I, Susurluk IA (2000) Türkiye için yeni bir entomopatojen nematod türü; Heterorhabditis marelatus Lui and Berry, 1996 (Rhabditida: Heterorhabditidae). Tar Bil Derg 6:59-64

Khatri-Chhetri HB, Waeyenberge L, Manandhar HK, Moens M (2010) Natural occurrence and distribution of entomopathogenic nematodes (Steinernematidae and Heterorhabditidae) in Nepal. J Inver Path 103:74-78 
Khatri-Chhetri HB, Waeyenberge L, Spiridonov SE, Manandhar HK, Moens M (2011a) Steinernema lamjungense n. sp. (Rhabditida: Steinernematidae), a new species of entomopathogenic nematode from Lamjung district, Nepal. Nematol 13:589-605

Khatri-Chhetri HB, Waeyenberge L, Spiridonov S, Manandhar HK, Moens M (2011b) Two new species of Steinernema Travassos, 1927 with short infective juveniles from Nepal. Russ J Nematol 19:53-74

Kulkarni N, Rizvi AN, Kumar V, Paunikar S, Mishra VK (2012) Morphological and molecular characterization of Steinernema dharanaii sp. n.: a new entomopathogenic nematode from India. I J Trop Biodiv 20:107-116

Lalramnghaki HC, Vanlalhlimpuia, Vanramliana, Lalramliana (2017) Characterization of a new isolate of entomopathogenic nematode, Steinernema sangi (Rhabditida, Steinernematidae), and its symbiotic bacteria Xenorhabdus vietnamensis (c-Proteobacteria) from Mizoram, north-eastern India. J Par Dis 41:1123-1131

Lee DW, Choo HY, Kaya HK, Lee SM, Smitley DR, Shin HK, Park CG (2002) Laboratory and field evaluation of Korean entomopathogenic nematode isolates against the oriental beetle Exomala orientalis (Coleoptera: Scarabaeidae). J Econ Ent 95:918-926

Lee MM, Sicard M, Skeie M, Stock SP (2009) Steinernema boemarei n. sp. (Nematoda: Steinernematidae), a new entomopathogenic nematode from southern France. Sys Par 72:127-141

Li XY, Liu QZ, Nermut' J, Půža V, Mráček Z (2012) Heterorhabditis beicherriana n. sp. (Nematoda: Heterorhabditidae), a new entomopathogenic nematode from the Shunyi district of Beijing, China. Zootaxa 3569:25-40

Liu J, Berry RE (1996) Steinernema oregonensis n. sp. (Rhabditida: Steinernematidae) from Oregon, USA. Fun App Nematol 19:375-380

Lopez-Nunez JC, Plichta K, Gongora-Botero CE, Stock SP (2008) A new entomopathogenic nematode, Steinernema colombiense n. sp. (Nematoda: Steinernematidae), from Colombia. Nem 10:561-574

Luc PV, Nguyen KB, Reid AP, Spridonov SE (2000) Steinernema tami sp. n. (Rhabditida: Steinernematidae) from Cat Tien forest, Vietnam. Russian J Nematol 8:33-43

Ma J, Chen S, Clercq DEP, Han R, Moens M (2012a) Steinernema changbaiense sp. n. (Rhabditida: Steinernematidae), a new species of entomopathogenic nematode from Northeast China. Russ J Nematol 20:97-112

Ma J, Chen S, Clercq DEP, Waeyenberge L, Han R, Moens M (2012b) A new entomopathogenic nematode, Steinernema xinbinense n. sp. (Nematoda: Steinernematidae), from North China. Nematol 14:723-739

Ma J, Chen S, Li X, Han R, Khatri-Chhetri HB, Clercq DEP, Moens M (2012C) A new entomopathogenic nematode, Steinernema tielingense n. sp. (Rhabditida: Steinernematidae), from north China. Nematol 14:321-338

Maafi ZT, Ebrahimi N, Abootorabi E, Spiridonov SE (2006) Record of two steinernematid species from Iran, Proceeding of 17th Iranian Plant Protection Congress, Razi University of Kermanshah, pp 482

Malan AP, Knoetze R, Moore SD (2011) Isolation and identification of entomopathogenic nematodes from citrus orchards and their biocontrol potential against false codling moth. J Inv Path 108:115-125

Malan AP, Knoetze R, Tiedt L (2014) Heterorhabditis noenieputensis n. sp. (Rhabditida: Heterorhabditidae), a new entomopathogenic nematode from South Africa. J Helmin 88:139-151

Malan AP, Knoetze R, Tiedt L (2015) Steinernema jeffreyense $n$. sp. (Rhabditida: Heterorhabditidae), a new entomopathogenic nematode from South Africa. J Helmin 90:262-278

Malan AP, Knoetze R, Tiedt L (2016) Steinernema nguyeni n sp. (Rhabditida: Steinernematidae), a new entomopathogenic nematode from South Africa. Nematol 18:571-590

Malan AP, Nguyen KB, De Waal JY, Tiedt L (2008) Heterorhabditis safricana n. sp. (Rhabditida: Heterorhabditidae), a new entomopathogenic nematode from South Africa. Nematol 10:381-396

Mamiya Y (1988) Steinernema kushidai n. sp. (Nematoda: Steinernematidae) associated with scarabaeid beetle larvae from Shizuoka, Japan. App Ent Zool 23:313-320

Maneesakorn P, Grewal PS, Chandrapatya A (2010) Steinernema minutum sp. nov. (Rhabditida: Steinernema): a new entomopathogenic from Thailand. Int J Nematol 20:27-42

Maneesakorn P, Grewal PS, Chandrapatya A (2015) Heterorhabditis somsookii sp. nov. (Rhabditida: Heterorhabditidae): a new entomopathogenic nematode from Thailand. Int J Nematol 11:1-17

Mekete T, Gaugler R, Nguyen KB, Mandefro W, Tessera T (2005) Biogeography of entomopathogenic nematodes in Ethyopia. Nematrop 35:31-35
Mhatre PH, Patil J, Kumar RV, Venkatasalam EP, Divya Kl, Jenifer J, Pankaj, Satish CN (2017) The first report of Steinernema cholashanense (Rhabditida: Steinernematidae) from India. Indian J Nematol 47:254

Molina-Ochoa J, Arceo-Palacios MA, Lezama-Gutierrez R, Gonzalez-Ramirez M, Rebolledo-Dominguez O, Lopez-Lavin M, Galindo-Velasco E, Zepeda-Jasso Al, Cardenas-Amescua JL (2003a) Susceptibilidad de Helicoverpa zea (Boddie) (Lepidoptera: Noctuidae) a Steinernema feltiae (Rhabditida: Steinenematidae). In: Vazquez-Garcia M, Perez Domanguez JF, Ibarra-Cortes K, Balpuesta-Leon C, Vazquez-Reyes R, Cervantes-Rios J, Ibara-Frias N (eds) Memorias del XXVI Congreso Nacional de Control Biológico. Sociedad Mexicana de Control biológico, Texcoco, México, pp 18-21

Molina-Ochoa J, Lezama-Gutierrez R, Gonzalez-Ramirez M, Lopez-Edwards M, Rodriguez-Vega MA, Arceo-Palacios F (2003b) Pathogens and parasitic nematodes associated with populations of fall armyworm (Lepidoptera: Noctuidae) larvae in México. In: Vazquez-Garcia M, Perez Domnaguez JF, Ibarra-Cortes K, Balpuesta-Leon C, Vazquez-Reyes R, Cervantes-Rios J, IbaraFrias N (eds) Memorias del XXVI Congreso Nacional de Control Biológico. Sociedad Mexicana de Control biológico, Texcoco, México, pp 14-17

Molina-Ochoa J, Rodriguez-Vega MA, Lezama-Gutierrez R, Gonzalez-Ramirez M, Lopez-Lavin M, Galindo-Velazco E, Rebolledo-Rodriguez O, Zepeda-Jasso Al, Cardenas Amescua JL (2003c). Susceptibilidad de larvas de Spodoptera frugiperda (J.E. Smith) (Lepidoptera: Noctuidae) in México. In: Vazquez-Garcia M, Perez Domnaguez JF, Ibarra-Cortes K, Balpuesta-Leon C, Vazquez-Reyes R, Cervantes-Rios J, Ibara-Frias N (eds) Memorias del XXVI Congreso Nacional de Control Biológico. Sociedad Mexicana de Control biológico, Texcoco, México, pp 10-13

Mráček Z, Hernandez EA, Boemare NE (1994) Steinernema cubana sp. n. (Nematoda: Rhabditida: Steinernematidae) and the preliminary characterisation of its associated bacterium. J Inver Path 64:123-129

Mráček Z, Liu QZ, Nguyen KB (2009) Steinernema xueshanense n. sp. (Rhabditida, Steinernematidae), a new species of entomopathogenic nematode from the province of Yunnan, southeast Tibetan Mts., China. J Inver Path 102:69-78

Mráček Z, Nguyen KB, Tailliez P, Boemare N, Chen S (2006) Steinernema sichuanense n. sp. (Rhabditida, Steinernematidae) a new species of entomopathogenic nematode from the province of Sichuan, east Tibetan Mts., China. J Inver Path 93:157-169

Mráček Z, Půža V, Nermut' J (2014) Steinernema poinari sp. n. (Nematoda: Steinernematidae) a new entomopathogenic nematode from the Czech Republic. Zootaxa 3760:336-350

Mráček Z, Sturhan D, Reid A (2003) Steinernema weiseri n. sp. (Rhabditida, Steinernematidae), a new entomopathogenic nematode from Europe. Sys Parasitol 56:37-47

Mwaniki SW, Nderitu JH, Olubayo F, Nguyen K (2008) Factors influencing the occurrence of entomopathogenic nematodes in the central rift valley region of Kenya. Afric J Ecol 46:79-84

Nguyen KB, Buss EA (2011) Steinernema phyllophagae n. sp. (Rhabditida: Steinernematidae), a new entomopathogenic nematode from Florida, USA. Nematol 13:425-442

Nguyen KB, Duncan LW (2002) Steinernema diaprepesi n. sp. (Rhabditida: Steinernematidae), a parasite of the citrus weevil Diaprepes abbreviatus (L.) (Coleoptera: Curculionidae). J Nematol 34:159-170

Nguyen KB, Ginarte CMA, Leite L, Santos JM, Harakava R (2010) Steinernema brazilense $\mathrm{n}$. sp. (Rhabditida: Steinernematidae), a new entomopathogenic nematode from Mato Grosso, Brazil. J Inver Path 103:8-20

Nguyen KB, Gozel U, Koppenhöfer HS, Adams BJ (2006a) Heterorhabditis floridensis n. sp. (Rhabditida: Heterorhabditidae) from Florida. Zootaxa 1 177:1-19

Nguyen KB, Půža V, Mráček Z (2008a) Steinernema cholashanense n. sp. (Rhabditida, Steinernematidae) a new species of entomopathogenic nematode from the province of Sichuan, Chola Shan Mountains, China. J Inver Path 97:251-264

Nguyen KB, Qiu L, Zhou Y, Pang Y (2006b) Steinernema leizhouense sp. n. (Nematoda: Steinernematidae), a new entomopathogenic nematode from southern China. Russ J Nematol 14:101-118

Nguyen KB, Shapiro-Ilan DI, Mbata GN (2008b) Heterorhabditis georgiana n. sp. (Rhabditida: Heterorhabditidae) from Georgia, USA. Nematol 10:433-448

Nguyen KB, Shapiro-Ilan DI, Stuart RJ, Mccoy CW, James RR, Adams BJ (2004a) Heterorhabditis mexicana n. sp. (Rhabditida: Heterorhabditidae) from Tamaulipas, Mexico, and morphological studies of the bursa of Heterorhabditis spp. Nematol 6:231-244

Nguyen KB, Smart GC Jr (1990) Steinernema scapterisci n. sp. (Steinernematidae: Nematoda) and a key to species of the genus Steinernema. J Nematol 22: 187-199 
Nguyen KB, Smart GC Jr (1992) Steinernema neocurtillis n. sp. (Rhabditida: Steinernematidae) and a key to species of the genus Steinernema. J Nematol 24:463-477

Nguyen KB, Smart GC Jr (1994) Neosteinernema longicurvicauda n. gen., n. sp. (Rhabditia: Steinernematidae), a parasite of the termite Reticulitermes flavipes (Koller). J Nematol 26:162-174

Nguyen KB, Stuart RJ, Andalo V, Gozel U, Rogers ME (2007) Steinernema texanum n. sp. (Rhabditida: Steinernematidae), a new entomopathogenic nematode from Texas, USA. Nematol 9:379-396

Nguyen KB, Tesfamariam M, Gozel U, Gaugler R, Adams BJ (2004b) Steinernema yirgalemense n. sp. (Rhabditida: Steinernematidae) from Ethiopia. Nematol 6:839-856

Nikdel M, Niknam G (2015) Morphological and molecular characterization of a new isolate of entomopathogenic nematode, Steinernema feltiae (Filipjev) from Arasbaran forests. Iran. J Asia-Pacific Biodiv:144-151

Nikdel M, Niknam G, Shojaee M, Askary H, Mohammadi SA (2008) A survey on the response of the last instar larvae of acorn weevil, Curculio glandium (Col.: Curculionidae), to entomopathogenic nematodes Steinernema bicornutum and Heterorhabditis bacteriophora in the laboratory. J Ent Soc Iran 28:45-60

Nikdel M, Niknam GR, Griffin CT, Kary NE (2010) Diversity of entomopathogenic nematodes (Nematoda: Steinernematidae, Heterorhabditidae) from Arasbaran forests and rangelands in the north-west of Iran. Nematol 12:767-773

Nikdel M, Niknam GR, Ye W (2011) Steinernema arasbaranense n. sp. (Nematoda: Steinernematidae), a new entomopathogenic nematode from Arasbaran forests, Iran. Nematolog Med 39:17-28

Nthenga I, Knoetze R, Berry S, Tiedt LR, Malan AP (2014) Steinernema sacchari n. sp. (Rhabditida: Steinernematidae), a new entomopathogenic nematode from South Africa. Nematol 16:475-494

Özer N, Keskin N, Kirbas Z (1995) Occurrence of entomopathogenic nematodes (Steinernematidae: Heterorhabditidae) in Turkey. Nematolog 41:639-640

Pereira C (1937) Rhabditis hambletoni n.sp. nema apparentemente semiparasito da "broca do algodoeiro" (Gasterocercodes brasiliensis). Arch Inst Biol 8:215-230

Phan KL, Nguyen NC, Moens M (2001a) Steinernema sangi sp. n. (Rhabditida: Steinernematidae) from Vietnam. Russ J Nematol 9:1-7

Phan KL, Nguyen NC, Moens M (2001b) Steinernema loci sp. n. and Steinernema thanhi n. sp. (Rhabditida: Steinernematidae) from Vietnam. Nematol 3:503-514

Phan KL, Nguyen NC, Moens M (2001c). Steinernema loci sp. n. and Steinernema thanhi sp. n. (Rhabditida: Steinernematidae) from Vietnam. Nematol 3:503-514

Phan LK, Mrácek Z, Půža V, Nermut' J, Jarošová A (2014) Steinernema huense sp. n., a new entomopathogenic nematode (Nematoda: Steinernematidae) from Vietnam. Nematol 16:761-775

Phan LK, Spiridonov SE, Subbotin SA, Moens M (2006a) Four new species of Steinernema Travassos, 1928 with short infective juveniles from Vietnam. Russ J Nematol 14:11-29

Phan LK, Subbotin SA, Nguyen CN, Moens M (2003) Heterorhabditis baujardi sp. n. (Rhabditida: Heterorhabditidae) from Vietnam with morphometric data for $\mathrm{H}$. indica populations. Nematol 5:367-382

Phan LK, Subbotin SA, Waeyenberge L, Moens M (2005) A new entomopathogenic nematode, Steinernema robustispiculum n. sp. (Rhabditida: Steinernematidae) from Chumomray National Park in Vietnam. Sys Parasitol 60:23-32

Phan LK, Takemoto S, Futai K (2006b) Steinernema ashiuense sp. n. (Nematoda: Steinernematidae), a new entomopathogenic nematode from Japan. Nematol 8:681-690

Pizano MA, Aguillera MM, Monteiro AR, Ferraz LCCB (1985) Incidence of Neoaplectana glaseri Steiner, 1929 (Nematoda: Steinernematidae) parasitizing Migdolus fryanus (Westwood, 1863) (Col.: Cerambycidae). Entom Newsl 17:9-10

Poinar GO (1990) Taxonomy and biology of Steinernematidae and Heterorhabditidae. In: Entomopathogenic nematodes in Biological Control. Gaugler R, Kaya HK (eds). CRC Press, Boca Raton. pp 23-61

Poinar GO Jr (1975) Entomogenous nematodes: a manual and host list of insectnematode associations. Brill, Leiden, Germany

Poinar GO Jr (1976) Description and biology of a new insect parasitic rhabitoid, Heterorhabditis bacteriophora n. gen. n. sp. (Rhabditida; Heterorhabditidae n. family). Nematologica 21:463-470

Poinar GO Jr (1985) Neoaplectana intermedia n. sp. (Steinernematidae: Nematoda) from South Carolina. Rev Nematol. 8:321-327

Poinar GO Jr (1986) Neoaplectana intermedia n. sp. (Steinernematidae: Nematoda) from South Carolina. Rev de Nématolog 8:321-327

Poinar GO Jr, Jackson T, Klein M (1987) Heterorhabditis megidis sp. $\mathrm{n}$. (Heterorhabditidae: Rhabditidia), parasitic in Japanese beetle, Popillia japonica (Scarabidae: Coleoptera), in Ohio. Proc Helmin Soc Wash 53:53-59
Poinar GO Jr, Karunakar GK, David H (1992) Heterorhabditis indicus n. sp. (Rhabditida, Nematoda) from India: separation of Heterorhabditis spp. by infective juveniles. Fund App Nematol 15:467-472

Půža V, Nermut J, Mráček Z, Gengler S (2017) Steinernema pwaniensis n. sp., a new entomopathogenic nematode (Nematoda: Steinernematidae) from Tanzania. J Helminth 91:20-34

Půža V, Campos-Herrera R, Blanco-Pérez R, Jakubíková H, Vicente-Díez I, Nermut' J (2020) Steinernema riojaense n. sp., a new entomopathogenic nematode (Nematoda: Steinernematidae) from Spain. Nematol. In press. https://doi.org/ $10.1163 / 15685411-00003343$.

Qiu L, Fang YU, Zhou Y, Pang Y, Nguyen KB (2004) Steinernema guangdongense sp. n. (Nematoda: Steinernematidae), a new entomopathogenic nematode from southern China with a note on S. serratum (nomen nudum). Zootaxa 704:1-20

Qiu L, Hu X, Zhou Y, Mei S, Nguyen KB, Pang Y (2005b) Steinernema akhursti n. sp. (Nematoda: Steinernematidae) from Yunnan, China. J Inver Path 90:151-160

Qiu L, Hu X, Zhou Y, Pang Y, Nguyen KB (2005c) Steinernema beddingi n. sp. (Nematoda: Steinernematidae), a new entomopathogenic nematode from Yunnan, China. Nematol 7:737-749

Qiu L, Yan Y, Zhou Y, Nguyen KB, Pang Y (2005a) Steinernema aciari sp n. (Nematoda: Steinernematidae), a new entomopathogenic nematode from Guangdong, China. J Inver Path 88:58-69

Qiu L, Zhao J, Wu Z, Lv Z, Pang Y (2011) Steinernema pui sp. n. (Rhabditida, Steinernematidae), a new entomopathogenic nematode from Yunnan, China. Zootaxa 2767:1-13

Rahatkhah Z, Karimi J, Ghadamyari M, Brivio MF (2015) Immune defenses of Agriotes lineatus larvae against entomopathogenic nematodes. BioCont 60: 641-653

Román J, Figueroa W (1994) Steinernema puertoricensis n. sp. (Rhabditida: Steinernematidae), a new entomopathogenic nematode from Puerto Rico. J Agril Univ Puerto Rico 78:167-175

Rosales ALC, Suarez HZ (1998) Nematodos entomopatogenos como posibles agentes de control del gorgojo negro del platano Cosmopolites sordidus (Germar, 1824) (Coleoptera: Curculionidae). Bol de Entom Venez, Série Monog 13:123-140

Ruiz-Vega J, Aquino-Bolaños T, Kaya HK, Stock P (2003) Colecta y evaluación de nemátodos entomopathágenos para el control de gallinas ciegas Phyllophaga vetula (Horn) en Oaxaca, México. Fol Entom Mex 42:169-175

Saenz A (1999) Evaluacion de procedimientos para el aislamento y almacenamiento del entomonematodo nativo Steinernema feltiae (Rhabditida: Steinernematidae). Rev Colomb Entom 25:209-215

Saleh MME, Alheji M (2003) Biological control of red palm weevil with entomopathogenic nematodes in the Eastern province of Saudi Arabia. Egyp J Biol Pes Cont 13:55-59

San-Blas E, Morales-Montero P, Portillo E, Nermut' J, Pưža V (2016) Steinernema goweni n. sp. (Rhabditida: Steinernematidae), a new entomopathogenic nematode from Zulia State, Venezuela. Zootaxa 4067:200-214

San-Blas E, Portillo E, Nermut' J, Půža V, Morales-Montero P (2015) Steinernema papillatum n. sp. (Rhabditida: Steinernematidae), a new entomopathogenic nematode from Venezuela. Nematol 17:1081-1097

Shahina F, Anis M, Reid AP, Rowe J, Magbool MA (2001) Steinernema pakistanense sp. n. (Rhabditida: Steinernematidae) from Pakistan. Int J Nematol 11:124-133

Shahina F, Salma J (2010) Laboratory evaluation of seven Pakistani strains of entomopathogenic nematode against stored grain insect pest Sitophilus oryzae L. Pak J Nematol 28:295-305

Shahina F, Tabassum KA, Salma J, Mehreen G, Knoetze R (2016) Heterorhabditis pakistanense n. sp. (Nematoda: Heterorhabditidae) a new entomopathogenic nematode from Pakistan. J Helmin 91:222-235

Shamseldean MM, Abou El-Sooud AB, Abd-Elgawad, MM, Saleh, MM (1996) Identification of a new Heterorhabditis species from Egypt, Heterorhabditis taysearae n. sp. (Rhabditida: Heterorhabditidae). Egyp J Biol Cont 6:129-138

Shapiro-Ilan DI, Stuart RJ, McCoy CW (2005) Characterization of biological control traits in the entomopathogenic nematode Heterorhabditis mexicana (Mx4 strain). Biol Cont 32:97-103

Shen CP, Wang GH (1992) Description and studies of an entomopathogenic nematode: Steinernema longicaudum sp. nov. In: Proceedings of the first national academy symposium of young and middle aged science and technology workers on plant protection. Chin Sc Tech Press Beij, Beijing, pp 220-231 
Shen CP, Wang GH (1991) Description and studies of an entomopathogenic nematode: Steinernema longicaudum sp. nov. Proceeding of the first national academy symposium. Chinese Science and Technology Press. pp 220-231

Spiridonov SE, Krasomil-Osterfeld K, Moens M (2004) Steinernema jollieti sp. n. (Rhabditida: Steinernematidae), a new entomopathogenic nematode from the American Midwest. Russ J Nematol 12:85-95

Spiridonov SE, Waeyenberge L, Moens M (2010) Steinernema schliemanni sp. n. (Steinernematidae; Rhabditida) - a new species of steinernematids of the 'monticolum' group from Europe. Russ J Nematol 12:175-190

Stack CM, Easwaramoorthy SG, Metha UK, Downes MJ, Griffin CT, Burnell AM (2000) Molecular characterisation of Heterorhabditis indica isolates from India, Kenya, Indonesia and Cuba. Nematol 2:477-487

Steiner G (1923a) Aplectana kraussei n. sp., eine in der Blattwespe Lyda sp. Parasitierende Nematoden Form, nebst Bemerkungenüber das Seitenorgan der parasitischen Nematoden. Zentr fur Bakter Parasit Infekt und Hyg Abteil 59:14-18

Steiner G (1923b) Aplectana kraussei n. sp., eine in der Blattwespe Lyda sp. Parasitierende Nematoden Form, nebst Bemerkungenüber das Seitenorgan der parasitischen Nematoden. Zen fur Bakt Parasit Infekt und Hyg Abt 59:14-18

Steiner G (1929) Neoaplectana glaseri n. g., n. sp. (Oxyuridae) a new nemic parasite of the Japanese beetle. J Wash Acad Sci 19:436-440

Steyn WP, Knoetze R, Tiedt LR, Malan AP (2017) Steinernema litchii n. sp. (Rhabditida: Steinernematidae), a new entomopathogenic nematode from South Africa. Nematol 19:1157-1177

Stock SP, Bana AL, Darwish R, Katbeh A (2008) Diversity and distribution of entomopathogenic nematodes (Nematoda: Steinernematidae, Heterorhabditidae) and their bacterial symbionts in Jordan. J Inver Path 98:228-234

Stock SP, Campos-Herrera R, El Borai F, Duncan LW (2019) Steinernema khuongi n. sp. (Panagrolaimomorpha, Steinernematidae) a new entomopathogenic nematode species from Florida, USA. J Helminthol 93:226-241

Stock SP, Choo HY, Kaya HK (1997) An entomopathogenic nematode, Steinernema monticolum sp. n. (Rhabditida: Steinernematidae) from Korea with a key to other species. Nematolog 43:15-29

Stock SP, Griffin CT, Chaerani R (2004) Morphological and molecular characterisation of Steinernema hermaphroditum n. sp. (Nematoda: Steinernematidae), an entomopathogenic nematode from Indonesia, and its phylogenetic relationships with other members of the genus. Nematolog 6: $401-412$

Stock SP, Griffin CT and Burnell AM (2002) Morphological characterisation of three isolates of Heterorhabditis Poinar, 1976 from the 'rish group' (Nematoda: Rhabditida: Heterorhabditidae) and additional evidence supporting their recognition as a distinct species, H. downesi n. sp. Syst Parasitol 51:95-106

Stock SP, Koppenhöfer AM (2003) Steinernema scarabaei n. sp. (Rhabditida: Steinernematidae), a natural pathogen of scarab beetle larvae (Coleoptera: Scarabaeidae) from New Jersey, USA. Nematol 5:191-204

Stock SP, Somsook V, Reid A (1998) Steinernema siamkayai n. sp. (Rhabditida: Steinernematidae), an entomopathogenic nematode from Thailand. Sys Parasitol 41:105-113

Stock SP, Strong D, Gardner SL (1996) Identification of Heterorhabditis (Nematoda: Heterorhabditidae) from California with a new species isolated from larvae of the ghost moth Hepialus californicus (Lepidoptera: Hepialidae) from the Bodega Bay Natural Reserve. Fund App Nematol 19: 585-592

Sturhan D, Spiridonov SE, Mráček Z (2005) Steinernema silvaticum sp. n. (Rhabditida: Steinernematidae), a new entomopathogenic nematode from Europe. Nematol 7:227-241

Tabassum KA, Salma J, Sagir H (2017) Two new records of entomopathogenic nematodes (Nematoda: Steinernematidae) from Gilgit-Baltistan, Pakistan. Pak J Nematol 35:157-173

Tallosi B, Peters A, Ehlers R-U (1995) Steinernema bicornutum sp. n. (Rhabditida: Steinernematidae) from Vojvodina, Yugoslavia. Russ J Nematol 3:71-80

Tamirou T, Waeyenberg L, Tesfaye H, Ehlers R-U, Půža V, Mráček Z (2012) Steinernema ethiopiense sp. n. (Rhabditida: Steinernematidae), a new entomopathogenic nematode from Ethiopia. Nematol14:741-757

Tarasco E, Clausi M, Rappazzo G, Panzavolta T, Curto G, Sorino R, Oreste M, Longo A, Leone D, Tiberi R, Vinciguerra MT, Triggiani O (2015)
Biodiversity of entomopathogenic nematodes in Italy. J Helmin 89:359-366

Tarasco E, Mráček Z, Nguyen KB, Triggiani O (2008) Steinernema ichnusae sp. n. (Nematoda: Steinernematidae) a new entomopathogenic nematode from Sardinia Island (Italy). J Inver Path 99:173-185

Tarasco E, Triggiani O, Sai K, Zanoum M (2009) Survey on entomopathogenic nematodes in Algerian soils and their activity at different temperatures. Frus Entom 32:31-42

Thanwisai A, Tandhavanant S, Saiprom N, Waterfield NR, Ke Long P, Bode HB, Peacock SJ, Chantratita N (2012) Diversity of Xenorhabdus and Photorhabdus spp. and their symbiotic entomopathogenic nematodes from Thailand. PLoS One 7(9):e43835 https://doi.org/10.1371/journal.pone.0043835

Travassos L (1927) Sobre o genera Oxysomatium. Bolet Biol 5:20-21

Triggiani O, Mráček Z, Reid A (2004) Steinernema apuliae sp. n. (Rhabditida: Steinernematidae): a new entomopathogenic nematode from southern Italy. Zootaxa 460:1-12

Tseng CT, Hou RF, Tang LC (2018) Steinernema taiwanensis n. sp. (Rhabditida: Steinernematidae), a new entomopathogenic nematode from Taiwan. Zootaxa 4434:466-480. https://doi.org/10.11646/zootaxa.4434.3.4

Ünlü I, Ehlers R-U, Susurluk IA (2007) Additional data and firs record of the entomopathogenic nematode Steinernema weiseri from Turkey. Nematol 9: 739-741

Uribe-Lorio L, Mora M, Stock SP (2005) First record of entomopathogenic nematodes (Steinernematidae and Heterorhabditidae) in Costa Rica. J Inver Path 88:226-231

Uribe-Lorío L, Mora M, Stock SP (2007) Steinernema costaricense n. sp. and Steinernema puntauvense n. sp. (Rhabditida: Steinernematidae), two new entomopathogenic nematodes from Costa Rica. Sys Parasitol 68: 167-182

Vanlalhlimpuia, Lalramliana, Lalramnghaki HC, Vanramliana (2018) Morphological and molecular characterization of entomopathogenic nematode, Heterorhabditis baujardi (Rhabditida, Heterorhabditidae) from Mizoram, northeastern India. J Parasit Dis pp 341-349

Wang H, Luan JB, Dong H, Qian HT, Cong B (2014) Natural occurrence of entomopathogenic nematodes in Liaoning (Northeast China). J Asia-Pacific Ent 17:399-406

Waturu CN (1998) Entomopathogenic nematodes (Steinernematidae and Heterorhabditidae) from Kenya. PhD Thesis, University of Reading, UK

Waturu CN, Hunt DJ, Reid AP (1997) Steinernema karii sp. n. (Nematoda: Steinernematidae), a new entomopathogenic nematode from Kenya. Int J Nematol 7:65-75

Weiser J (1955) Neoaplectana carpocapsae n. sp. (Anguillulata: Steinernematinae), novy cizopasník housenek obaleče jablečného, Carpocapsa pomonella L. Věst Českoslov Zool Spol 19:44-52

Wouts W, Mráček Z, Gerdin S, Bedding RA (1982) Neoaplectana Steiner, 1929 a junior synonym of Steinernema Travassos, 1927 (Nematoda: Rhabditida). Sys Parasitol 4:147-154

Xu Z, Wang G, Li X (1991) A new species of the genus Steinernema (Rhabditida: Steinernematidae). Zoo Res 12:17-20

Yan X, Waweru B, Qiu X, Hategekimana A, Kajuga J, Li H, Edgington S, Umulisa S, Han R, Toepfer S (2016) New entomopathogenic nematodes from semi-natural and small-holder farming habitats of Rwanda. Biocont Sc Tech 26:820-834

Yılmaz H, Waeyenberge L, Demirbağ Z, Moens M (2007) First record of Heterorhabditis megidis (Rhabditida: Heterorhabditidae) from Turkey. International Crop Protection Symposium, May 22, Gent, Belgium, pp 59

Yooyangket T, Muangpat P, Polseela R, Tandhavanant S, Thanwisai A, Vitta A (2018) Identification of entomopathogenic nematodes and symbiotic bacteria from Nam Nao National Park in Thailand and larvicidal activity of symbiotic bacteria against Aedes aegypti and Aedes albopictus. PLoS One 13(4):e0195681 https://doi.org/10.1371/journal.pone.0195681

Yoshida M (2005) Steinernema litorale n. sp. (Rhabditida: Steinernematidae) a new entomopathogenic nematode from Japan. Nematol 6:819-838

Yoshida M (2004). Steinernema litorale n. sp. (Rhabditida:Steinernematidae), a new entomopathogenic nematode from Japan. Nematol 6:819-838

Yoshida M, Reid AP, Briscoe BR, Hominick WM (1998) Survey of entomopathogenic nematodes (Rhabditida: Steinernematidae and Heterorhabditidae) in Japan. Fund App Nematol 21:185-198

Zadji L, Baimey H, Afouda L, Houssou GF, Waeyenberge L, de Sutter N, Moens M, Decraemer W (2013) First record on the distribution of entomopathogenic 
nematodes (Rhabditida: Steinernematidae and Heterorhabditidae) in Southern Benin. Russ J Nematol 21:117-130

Zamoum M, Berchiche S, Sai K, Triggiani O, Tarasco E (2011) Preliminary survey of the occurrence of entomopathogenic nematodes and fungi in the forest soils of Algeria. Silva Lusit 19:141-145

\section{Publisher's Note}

Springer Nature remains neutral with regard to jurisdictional claims in published maps and institutional affiliations.

Submit your manuscript to a SpringerOpen ${ }^{\odot}$ journal and benefit from:

- Convenient online submission

- Rigorous peer review

- Open access: articles freely available online

- High visibility within the field

- Retaining the copyright to your article

Submit your next manuscript at $\boldsymbol{\nabla}$ springeropen.com 